\title{
Comportamentos de cidadania organizacional em educadores de infância da rede pública e privada
}

\section{Organizational citizenship behaviors of preschool teachers from public and private sector}

DOI: $10.46814 / \operatorname{lajdv} 4 n 1-010$

Recebimento dos originais: 01/01/2021

Aceitação para publicação: 28/02/2022

\author{
Paula C. Neves \\ Doutora \\ Escola Superior de Educação - Instituto Politécnico de Coimbra- Rua Dom João III, Solum \\ 3030-329 Coimbra, Portugal \\ Centro de Estudos Interdisciplinares do Século XX da Universidade de Coimbra - CEIS 20 \\ E-mail: pneves@esec.pt \\ Ana Coelho \\ Doutora \\ Escola Superior de Educação - Instituto Politécnico de Coimbra- Rua Dom João III, Solum \\ 3030-329 Coimbra, Portugal \\ Centro de Estudos Interdisciplinares do Século XX da Universidade de Coimbra - CEIS 20 \\ E-mail: ana@esec.pt
}

\begin{abstract}
Several studies have identified the nature and characteristics of organizational citizenship behaviors (OCB) in primary and secondary education teachers, but research in the field of preschool education is almost non-existent. Empirical evidence of the impact that this type of behavior has on the functioning of any organization and the particularities of the roles of preschool teachers in relation to those of other teachers, justify conducting studies on this topic with early childhood education professionals. This paper presents the conclusions of a qualitative study carried out with public and private preschool teachers. The organizational citizenship behaviors performed by these professionals are identified, as well as personal and contextual factors that influence them. The data was collected in interviews with preschool teachers and was analyzed following the Grounded Theory procedures, in particular the constant comparison technique (Glaser \& Strauss, 1967). In a second moment, the data was discussed with different participants in a focus group. Data analysis indicates that although preschool teachers tend to view most of the activities they develop as central dimensions of their specific professionality, therefore not describing them as OCBs, it is possible to identify some forms of OCBs specific to preschool teachers, either at the professional level (pedagogical and/or organizational) and at the interpersonal level (activities focused on the relationship with children and families). Major divergences were identified in the dimension of providing care.
\end{abstract}

Keywords: Organizational citizenship behaviors, Preschool teachers, Professionality.

\section{RESUMO}

Vários estudos identificaram a natureza e as características dos comportamentos de cidadania organizacional (OCB) nos professores do ensino primário e secundário, mas a investigação no campo da educação pré-escolar é quase inexistente. As provas empíricas do impacto que este tipo de 
comportamentos tem no funcionamento de qualquer organização e as particularidades dos papéis dos professores do ensino pré-escolar em relação aos de outros professores, justificam a realização de estudos sobre este tema com profissionais da educação infantil. Este documento apresenta as conclusões de um estudo qualitativo realizado com professores do ensino pré-escolar públicos e privados. São identificados os comportamentos de cidadania organizacional desempenhados por estes profissionais, bem como os factores pessoais e contextuais que os influenciam. Os dados foram recolhidos em entrevistas com professores do ensino pré-escolar e foram analisados segundo os procedimentos da Grounded Theory, em particular a técnica de comparação constante (Glaser \& Strauss, 1967). Num segundo momento, os dados foram discutidos com diferentes participantes num grupo focal. A análise dos dados indica que embora os professores do pré-escolar tendam a ver a maioria das actividades que desenvolvem como dimensões centrais da sua profissionalidade específica, não os descrevendo portanto como OCBs, é possível identificar algumas formas de OCBs específicas para professores do pré-escolar, quer a nível profissional (pedagógico e/ou organizacional) quer a nível interpessoal (actividades centradas na relação com crianças e famílias). Foram identificadas grandes divergências na dimensão da prestação de cuidados.

Palavras-chave: Comportamentos de cidadania organizacional, Professores do pré-escolar, Profissionalidade.

\section{INTRODUCTION}

The concept of organizational citizenship behavior (OCB), initially proposed by Smith, Organ and Near (1983), is defined by Organ (1988, p.4) as "discretionary individual behavior, not directly or explicitly recognized by the formal system of rewards and which as a whole promotes the efficient functioning of the organization”. The importance and relevance of the study of OCBs lies in their strong contribution to the performance and effectiveness of organizations (Podsakoff, MacKenzie, Paine, \& Bachrach, 2000).

Research on OCB, although initially related to the business context (Podsakoff et al., 2000), was later extended to the education sector (DiPaola \& Neves, 2009; DiPaola \& Tschannen-Moran, 2001; Somech \& Drach-Zahavy, 2000). In educational institutions, research has provided evidence that, in schools that function satisfactorily teachers do not limit their activities to those formally required, but perform others that, not being mandatory, make a difference because they have impact on students' performance (DiPaola \& Hoy, 2005; Oplatka, 2009). In fact, to achieve their goals, schools depend on the availability of teachers to exert significant efforts beyond the formal requirements of their functions (Bogler \& Somech, 2004; Somech \& Bogler, 2002).

Research on this issue in the field of education, although still not common, has been carried out essentially with teachers and is almost non-existent in the context of childhood education (Oplatka \& Stundi, 2011). 
In this regard, the literature has identified three broad categories of teachers' OCB: studentdirected behaviors (e.g. keeping up-to-date pedagogically and scientifically; staying after hours to help students); peer-directed behaviors (e.g. supporting new teachers, sharing materials, relieving overworked peers); school-focused behaviors (e.g. volunteering for extra assignments, making suggestions for improvement) (Christ, Van Dick, Wagner, \& Stellmacher, 2003; Somech \& Bogler, 2002; Somech \& Drach-Zahavy, 2000).

Since the practice and professional contexts of preschool teachers' career and work differ from those of other schoolteachers, the data found in the investigation with the last ones cannot be generalized to preschool teachers.

In this context a qualitative investigation was planned to identify the behaviors of preschool teachers that can be considered OCB (e.g. behaviors that are not part of their formal obligations) and describe their perspectives of the personal and contextual determinants of OCB in preschool education.

This article presents the final global data of the study carried out over two years (Neves \& Coelho, 2013, 2013a; 2015).

\section{METHOD}

The overall methodology of this study corresponds to an inductive approach, in which data collection was carried out through semi-structured interviews and a focus group.

Initially, preschool teachers working in the public network were interviewed, in a second moment private and social sector educators were also interviewed, and later a focus group was held with educators from both systems. The selection criteria used for all participants in each phase was the number of years of work in each sector (at least 8 years). That is, educators whose work experience had been predominantly carried out either in the private sector or in the public sector.

In the first two phases of the study, during the interviews, the preschool teachers were invited to identify the activities/behaviors that they considered as mandatory, and those that, although not mandatory, they performed. They were also asked to identify the intervening factors (stimulating or inhibiting) in carrying out the second type of behaviors.

The data collected with each group of interviewees were later analyzed following the procedures of the Grounded Theory (Glaser \& Strauss, 1967), in particular the technique of constant comparison.

\section{RESULTS}

In both groups of preschool teachers, the inductive analysis of the interviews showed a predominant idea: the difficulty in demarcating boundaries and clearly differentiating what constitutes a mandatory and discretionary activity for the preschool teacher, whether in public or private system. 
The idea that functions are volatile and vary from institution to institution, that is "it depends on the institution where we work", was central in educators' discourse throughout the interviews.

The link between the functions and activities developed by the preschool teachers and the characteristics of their contexts, specifically the internal regulations and the institutional leadership, emerged as a central characteristic of their discourse. In educators from private sector, it became clear that there are institutions "where nothing is mandatory, there is total autonomy" and others where what the educators have to do is clearly defined and their "autonomy is very limited".

However, like Oplatka and Stundi (2011), it was also possible to identify in their speeches some forms of OCB, which were organized into two broad categories: professional (pedagogical and organizational activities) and interpersonal (activities focused on the relationship with children and families).

Although in the private sector the limits of educators functions seem to be linked to the rules and regulations of the institutions, the analysis of the interviews allowed us to understand that, from a professional point of view, in the pedagogical/curricular scope, educators who work in the private sector report the same type of activities as non-mandatory (and therefore OCB), as their colleagues working in the public sector.

This is the case of the use of participatory pedagogies (Oliveira-Formosinho, 2007), which ensure the child's involvement in the decision-making process and in the curriculum management, and the definition of procedures to regulate practices, in particular the use of forms of documentation education rather than standardized assessment tools. Although the child-centered methodological options correspond to the principles set out in the regulations that frame professional practices in pre-school education in Portugal, namely in the Curriculum Guidelines for Pre-School Education (Ministério da Educação, 1997), these educators do not view them as mandatory and, in many cases, do not seem to integrate those approaches in their pedagogical practices.

However, at the organizational level, differences are evident between the testimonies of preschools teachers from public and private sectors. Private sector educators report that they take on responsibilities and carry out functions other than the pedagogical ones, namely monitoring the children in their routines, which they consider should be performed by assistants. Thus, participating in children's routines (e.g. lunchtime), participating in organizational tasks (schedules, organizing spaces, routines), working as a team member or planning events together, seem be or not considered $\mathrm{OCB}$, depending on the institution where the educator works.

In the organizational level, it was, however, possible to identify points of convergence between the two groups of educators (public and private). This is the case of effective availability to extend the activity beyond the formally stipulated timetable; effective participation in the institution's meetings 
and initiatives conducted for process improvement (although this aspect is conditioned to the existence or not of these practices in the institutions); and the search for training, as a strategy and condition for professional development and improvement of their pedagogical practice. In the interpersonal domain, the intentionality of listening to children, together with providing an educational environment that is both challenging and secure, are also seen by the two groups of preschool teachers as options that depend on "the educator's sensitivity and professionalism" and on their understanding "of what it is to be an educator". The differences that emerge in this context result from the fact that educators from private sector often assume some tasks of assistants in specific "care" actions (e.g. hygiene, food,...), which in public are assumed as OCB and in private may or may not have this status. Also in the interpersonal sphere, the deepening of the relationship with the parents, and the definition of true partnership processes, are presented by both groups as OCB, which means that these are behaviors they can choose to do or not to do.

Finally, the statements about antecedents, facilitating and/or explanatory factors of the educators' OCBs are also different for the two groups. While educators from public sector essentially enhance individual factors, such as vocation, love for the profession or personal responsibility, educators from private sector, although also mention vocation and responsibility, place special emphasis on aspects related to the contextual characteristics. They emphasize in particular the importance of the organization's culture and interpersonal climate, especially the leadership styles. About leadership, they essentially emphasize its decisive role in establishing the limits of the educators' functions, as well as in encouraging or inhibiting their personal autonomy and freedom of choice, which is the essence of the OCB.

Although some individual situations, such as tiredness, lack of motivation or, at the limit, lack of vocation, appear both in the public and private sectors, it is in the private sector that organizational factors emerge with greater emphasis, reinforcing the idea that a good organizational climate and supportive leadership are conditions for involvement in OCB.

As mentioned, in the third moment of data collection, considering the need to clarify and deepen the data obtained through individual interviews, a focus group was held with other educators from both the public and private networks, in which the same themes were discussed.

The difficulty in setting the limits and clearly differentiating what constitutes a mandatory and a discretionary activity for the preschool teachers (previously identified in the two groups interviewed) was consensual among the participants. However, although there was agreement that functions are volatile and depend largely on whether they are performed in the public or private sector, the group was unable to reach a consensus on the "status" of care-related tasks (hygiene, food...). 
From a professional point of view, in the pedagogical/curricular scope, the participants confirmed some activities identified in the interviews as discretionary, such as the use of participatory pedagogies (Oliveira-Formosinho, 2007), and the definition and design of means to regulate practices, in particular the use of forms of pedagogical documentation instead of standardized assessment forms.

In an organizational level, four other areas were identified as being associated with the occurrence of OCBs. First, the level of training (of them and of the assistants). The active search for pedagogical training and updating as a strategy and condition for practices improvement and for personal professional development, as well as the concern to supervise and train assistants, were widely agreed upon as essential but clearly understood as discretionary, that is OCB. Second, the availability and initiative to collaborate with peers, namely in the preparation and sharing of materials and knowledge. Thirdly, participation in the institution's life, through active participation in meetings and team initiatives, and the availability for involvement with the team in collaborative processes. And finally, the effective availability to extend the activity beyond the formal timetable, this being a condition considered essential for the development of the other listed OCBs.

Finally, in relation to the personal and contextual determinants of OCB of preschool teachers, the emphasis on aspects that relate to a personal sphere was confirmed. Vocation, love for the profession, personal responsibility, and initial training are some of the arguments collected, which, together, are organized around the idea that OCBs are an ethical responsibility, which depends on each one. It is also in the personal sphere that educators place the main obstacles to OCBs, which are mainly related to situations of tiredness, lack of motivation or, at the limit, lack of vocation. Life circumstances, such as having young children or being placed in an area far from the area of residence, can also affect the capacity for more effective involvement and availability for OCBs.

It should be noted that the reference to organizational factors, although generically appearing in a subsidiary way in relation to these of a personal nature, also highlight the idea that a good institutional climate is a condition for involvement in OCB. However, educators working in the private sector place greater emphasis on aspects related to the context in which the practices are carried out, essentially emphasizing their determining role either in delimiting the limits of the function, or as an encourager or inhibitor of autonomy and freedom of choice that are at the base of OCBs. The educators assumed that, in the private sector, there is an assumption of responsibilities and the execution of other tasks beyond the pedagogical ones, namely functions of monitoring the children in the care routines, which for some of the educators (in particular from the public sector) should be assumed by the assistants. 


\section{FINAL CONSIDERATIONS}

The research on OCB of preschool teachers is a recent area of research, and the study that is now reported aims to contribute to the understanding of how educators see their missions and conceptualize the boundaries between what can be considered a professional obligation and an option that transcends it.

Although there was a consensus among all participants regarding the difficulty in demarcating the boundaries and clearly differentiating of what constitutes a mandatory and a discretionary activity for the preschool teacher, both in public and in the private sector, based on interviews with educators from both sectors and a focus group, it was possible to identify a consensus regarding a set of behaviors both professionally (pedagogical and organizational activities) and interpersonal (activities focused on the relationship with children and families) that are understood as OCBs.

However, the nature and characteristic of the provision of care has cleared emerged as a central dimension and source of disagreement among participants. This data seems relevant to us and requires further study, since the definition of what "educating" and "caring" means clearly refers to one of the central dimensions of the professionality of preschool teachers. In fact, it has been widely assumed that the broadening of responsibilities that characterizes this professional group, compared to other teachers, leads to blurring of boundaries (Katz \& Goffin, 1990), affecting their own representations as professionals, whether in positive or negative terms (Oliveira-Formosinho, 2000). 


\section{REFERENCES}

Bogler, R., \& Somech, A. (2004). Influence of teacher empowerment on teachers'organizational commitment,professional commitment and organizational citizenship behavior. Teaching and Teacher Education, 20, 277-289.

Christ, O., Van Dick, R., Wagner, U., \& Stellmacher, J. (2003). When teachers go the extra mile: Foci of organisational identification as determinants of different forms of organisational citizenship behaviour among schoolteachers. British Journal of Educational Psychology, 73, 329-341 .

DiPaola, M. F., \& Hoy, W. K. (2005b). Organizational citizenship of faculty and achievement of high school students. The High School Journal, 88, 35-44.

DiPaola, M. F., \& Neves, P. C. (2009). Organizacional citizenship behaviors in American and Portuguese public schools: Measuring the construct across cultures. Journal of Educational Administration, 47, 490-507.

DiPaola, M. F., \& Tschannen-Moran, M. (2001). Organizational citizenship behavior in schools and its relationship to school climate. Journal of School Leadership, 11, 424-447.

Glaser, B., \& Strauss, A. L. (1967). The discovery of grounded theory: Strategies for qualitative research. Chicago: Aldine

Katz, L., \& Goffin, S. (1990). Issues in the preparation of teachers of young children. Em B. Spodek, \& O. Saracho, Yearbook in early childhood education (Vol. 1): Early childhood teacher preparation. (pp. 192-208). New York: Teachers College Press (pp. 192-208). New York: Teachers College Press.

Neves, P. C., \& Coelho, A. (2013). Comportamentos de cidadania organizacional em educadores de Infância. Formação Profissional: Investigação educacional sobre teorias, políticas e práticas. Atas do XX Colóquio. Lisboa: EDUCA/Secção Portuguesa da AFIRSE., (pp. 1190-1194).

Neves, P. C., \& Coelho, A. (2013a). Comportamentos de cidadania organizacional em educadores de infância. Atas do XII Congresso Internacional Galeco-Português de Psicopedagogia (pp. 501-507). Braga: CIED - Centro de Investigação em Educação, Instituto de Educação, Universidade do Minho.

Neves, P. C., \& Coelho, A. (2015). Comportamentos de cidadania organizacional em educadores de infância. Diversidade e complexidade da avaliação em educação e formação. Atas do XXII Colóquio da AFIRSE Portugal (pp. 1570-1577). Lisboa: Instituto de Educação da Universidade de Lisboa.

Oliveira-Formosinho (2007). Pedagogia(s) da infãncia. Dialogando com o passado. Porto Alegre: ArtMed.

Oplatka, I. (2009). Organizational citizenship behavior in teaching : The consequences for teachers, pupils and the school. International Journal of Educational management, 23, 375-289.

Oplatka, I., \& Stundi, M. (2011). The components and determinants of preschool teacher organizacional citizenship behaviour. International Journal of Educational Management, 25 (3), 223 236.

Organ, D. W. (1988a). Organizational citizenship behavior : The good soldier syndrome. Lexington MA: Lexington Books. 
Podsakoff, P. M., MacKenzie, S. B., Paine, J. B., \& Bachrach, D. G. (2000). Organizational citizenship behaviors: A critical review of the theoretical and empirical literature and suggestions for future research. Journal of Management, 26, 513-563.

Smith, C. A., Organ, D. W., \& Near, J. P. (1983). Organizational citizenship behavior: Its nature and antecedents. Journal of Applied Psychology, 68, 653-663.

Somech, A., \& Bogler, R. (2002). Antecedents and consequences of teacher organizational and professional commitment. Educational Administration Quarterly, 38, 555-577.

Somech, A., \& Drach-Zahavy, A. (2000). Understanding extra-role behavior in schools: The relationships between job satisfaction, sense of efficacy, and teachers' extra-role behavior. Teaching and Teacher Education, 16, 649-659. 